\title{
ヒト汗のPAG 電気泳動像*
}

\author{
新津ひさえ ${ }^{* *}$ ・中屋敷徳** \\ 熊谷礼子** 桂 秀策**
}

\begin{abstract}
Summary
Sweats were obtained from 54 healthy adult men in a sauna. Supernatants of the sweats after centrifugation were dialyzed with deionized water and lyopholized. The sweat samples dissolved in normal saline were tested by PAG-slab electrophoresis. The sweat samples obtained from the 52 men were stained with Coomassie brilliant blue R250 and those from the 54 men were with PAS. The results were as follows : All the sweat samples had one band corresponding with the electrophoretic mobility of serum albumin. Two bands seemed to be important components of sweats were in the $\alpha$-globulin region of serum. Individual differences of electrophoretic patterns of the sweat samples

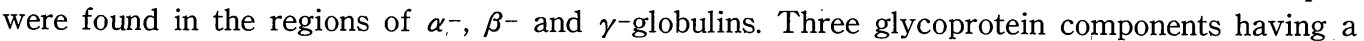
individually different mobility were observed in the pre-albumin region.
\end{abstract}

Key words : sweat, protein, PAG-slab electrophoresis, individual difference.

\section{緒}

\section{言}

凝集素吸収試験や型的凝集阻止試験などにより血痕 の血液型検查を行う場合，その担体に汗が付着してい ても，汗の型物質が血痕の型判定に殆ど影響しな ( ${ }^{122) 3)}$. しかし, 凝集素解離法4), 型的二重結合反応法5), Mixed cell agglutination reaction (MCAR) 法6)ある いは酵素抗体法7)などの鋭敏な検查法による場合は, 血痕担体にある汗などの型質による影響は大きく，型 誤判の原因ともなる。一方, 着衣などから汗を証明し, その血液型を知ること，また，もし汗蛋白に多型があ れば，これを利用して法医学で重要な個人識別を行う ことができる。以上を文献的に検討する。

Jirka and $\operatorname{Kotas}^{8)}$ は, heat box で集めたエクリン腺 とアポクリン腺の汗をポーラログラフィーで検査し,
汗には，ムコ蛋白の性質を有する蛋白があると報告し た. Cier ら ${ }^{9}$ は, 濾紙電気泳動の他に殿粉ゲル電気泳動 で, 汗を電気泳動し alb の陽極側に 1 本の, 院極側に 3 本のバンドがみられ, $\gamma$-globの陰極側には 3 本のバン ドがあることを観察した. Page and Remington ${ }^{10)} は$ セルロースアセテート膜電気泳動で，少なくとも 3 種 の汗の蛋白分画をみており，ある例では，さ.らにもう 1 種の分画があることを観察した. Jirka and Blanicky ${ }^{11)}$ は，ピロカルピンで得た汗をマイクロ等電 点電気泳動して数種の分画を観察し，その大部分は PAS 反応が陽性であり,電気泳動像に量的差を思わせ る差があることを報告した. Herrmann and Habbig ${ }^{12)}$ は，寒天電気泳動で汗には 4 分画があるとし，各分画 のエステラーゼ活性などを検查した. Uyttendaele ら ${ }^{13)}$ は, アガロース等速電気泳動を行い, サウナで採取

* PAG electrophoretic patterns of human sweats.

** Hisae Niitsu, Nori Nakayashiki, Reiko Kumagai, Syusaku Katsura, 岩手医科大学医学部法医学教室. （受付1984年10月11日，受理1984年11月10日） 
した汗には主要な 3 分画があり, その主バンドは alb に相当するとし，またズダン黒 B 染色により 3 個の lipophilic 分画が, PAS 染色により2 個の糖蛋白分画 が染色されたことを報告した. Rubin and Penneys ${ }^{14)}$ は, 汗を 2 次元ポリアクリルアミドゲル電気泳動し, fluorography と radioautographyにより検查し，一 般には 56 spotsをみたが, best preparation では 90 spotsを算え，多くの小変異が個人間にみられること を報告した。

以上のように，電気泳動法，汗濃度などにより，結 果は一様でないが，七ト汗には種々の蛋白分画が存在 するとみられ，中でも，Jirka and Blanicky ${ }^{11}$, Herrmann and $\mathrm{Habbig}^{12)}$, Rubin and Penneys ${ }^{14)} の$ 報告は, 汗蛋白分画には個人差のあることを示唆している.

汗の血清学的研究では, Jirka and Masopust ${ }^{15) 16)}$ は, ウサギ抗ヒ卜汗血清で二元免疫拡散法を行い，汗には 4 本の沈降線があり，うち 2 本は血清成分と考えた。 そのうち 1 本の沈降線は，すべてのヒトにあるとは限 らなかったという。また，免疫電気泳動法では 5 本の 沈降線を観察した. Page and Remington ${ }^{10)}$ は, ウサ ギ抗七ト汗血清で, 二元免疫拡散法を行い, 汗には 5 本の沈降線が生じたといい，男 6 人の汗では，抗 IgG 血清と 1 本の沈降線を作る 5 人と， 2 本の沈降線を作 る 1 人がいたことを報告した．また，汗に IgM がある とみられたのは 1 人だけであった。さらに，上卜汗に は IgGなど 8 種の血清成分を証明した. Herrmann and Habbig ${ }^{17)}$ は，ヒト汗に特異的なウサギ抗七ト汗血 清で，サウナで採取した汗と免疫電気泳動を行い， $\mathrm{P}_{1}$ $\sim \mathrm{P}_{8}$ と名付ける 8 本の沈降線を観察した。 このうち 3 本は血清蛋白に由来する alb, Tf, IgG であり, 不明の 3 本の沈降線はエクリン腺の産物であろうと考えた. さらに彼ら ${ }^{12) 18}$ は, 二元免疫拡散法, 寒天電気泳動法に より,七ト汗には 5 種類のエステラーゼがあるとした。 Takizawa ら ${ }^{199}$ は， ヒト汗に特異的に反応する沈降素 を作り，その抗原は汗の中の分子量約 30,000, pI 4 の 糖蛋白であるとした。

以上，通覧したようにヒト汗には汗個有の蛋白と多 型が存在するように考えられる。

\section{実験材料ならびに実験方法}

\section{1. 汗}

汗は54人の健康男性から採取した。サウナで，先ず 全身を石鹼で清浄に洗った後, $85^{\circ} \mathrm{C}$ 前後の空気に体を
さらし，涌出する汗をプラスチック製ビーカーに集め た. 採取した汗は, 各々 10,000 回転20分間遠心し, 上 清を分取して $1.0 \mu \mathrm{m}$ の孔を有するメンブランフィル ターで濾過して濾液を得た。これを蒸留水で 2 日間透 析し, 凍結乾燥し, 汗の乾燥重量を計った。

\section{PAG 平板ディスク電気泳動}

Davis $^{20)}$ の方法にしたがい, Polyacrylamide gel （PAG）濃度が7.5\%になるようにして分離ゲルを作 製した. Coomasie brilliant blue R250 (C.1.42660, CBB）染色 ${ }^{21}$ のための電気泳動には, 乾燥汗を生食液 で $15 \mathrm{mg} / \mathrm{ml}$ 濃度に溶解し, Lowry 法 ${ }^{22)} に よ り$ 蛋白濃 度を測定した。そして汗蛋白が $0.07 \mathrm{mg}$ と一定になる ように試料溝に10～30 $\mu 1$ の汗溶液を添加した. Periodic acid Schiff（PAS）染色 ${ }^{23)}$ のための電気泳動には $30 \mu 1$ を添加して行った. 対照として正常血清の 2 倍希 釈液 $20 \mu 1$ を用いた。泳動には, トリスグリシン緩衝液

(pH8.3)を用い, $100 \mathrm{~V}, 4$ 時間泳動した。なお，同一 検体について少なくとも 2 回反復泳動して検査した.

\section{実 験 成 績}

\section{CBB 染色像 (Fig. 1, Table 1)}

Coomassie brilliant blue R250 (C.1.42660, CBB) 染色による電気泳動像には, 血清の $\gamma^{-}, \beta^{-}, \alpha$-各 glob 領域, alb, pre-alb 領域に相当してそれぞれバンドが みられた (Fig. 1). $\gamma$-glob 領域を原点付近と陽極側に 分けると原点付近には，52総検体中 7 検体（13\%）に 3 本のバンドがみられ (Fig. 1, Nos. 7，22，36)，34 検体に (65\%) 2 本のバンドがみられた (Nos. 6，45). その他，1本のもの $(13 \%)$ や無いものもあった（ $8 \%)$. $\gamma$-glob 領域陽極側には Fig. 1 の Nos. 6，45のように 多くの汗にバンドはみられなかったが $(60 \%)$, Nos. $7 ， 22 ， 36$ のうに 2 本出現したものがあり（6\%)， またNos.15，47，50のように 1 本のものもあった (35\%). $\beta$-glob 領域には殆どの汗にバンドは生じな かったが (98\%), Fig.1のNo.7のように例外的にバ ンドがみられたものもあった ( $2 \%)$. Tf 領域には多く はバンドが現れないが(83\%), Nos.22, 36のように 1 本のバンドがあるものがあった $(17 \%) ＼alpha$-glob 領域 には 2 ～本のバンドがあり, Nos. 6, 7，15のよう に 3 本のものと $(40 \%), N o s .36,50$ のように 4 本ある ものが割に多かった(38\%)。一方，Nos.22，45，47に 示すように 5 本のバンドを有するものや $(8 \%) ， 2$ 本 しかない例もあった $(12 \%)$ 。また，判定困難な例が 1 
検体あった。

$\alpha$-glob 領域のバンドを移動度からみると，血清の $\alpha_{2}$ の少しく㓌極側に一般に CBB 染色で濃染するバン ドがあり，これは52検体全部にみられた。仮に，これ を $\alpha$-glob 領域主バンドと名付けておく。このバンド の陰極側に, 少しく離れて $\alpha$-glob 領域主バンドより 淡く染るバンドか 51 検体（98\%）にみられた。これら

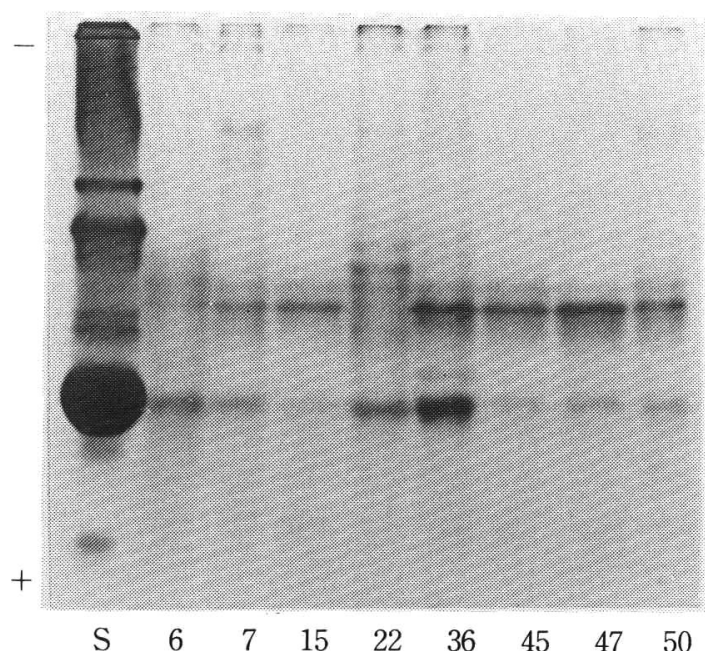

Fig.1. PAG electrophoretic patterns of human sweat and serum, CBB staining.

S : Normal human serum, Nos : Sweat sample numbers.
は, バンドの染色濃度, 出現頻度から汗検体の $\alpha$-glob 領域における二大バンドとみなされる。この主バンド の陽極側には淡い細いバンドが32検体 $(62 \%)$ にあり， 二大バンドの㓌極側，すなわち Fig. 1, No.22の $\alpha$ glob 領域で最も良く染っているバンドの移動度に一 致してバンドがみられたものが25検体 (48\%) あった。 alb 領域には alb 移動度に一致して総ての汗に 1 本 のバンドがみられた $(100 \%)$. pre-alb 領域には淡いバ ンドが広い範囲にみられ，判然としないが，速く移動 するもの (No.47) と遅く移動するもの (No.6), さら にこれらの両方に広がっているように観られるもの (No.50) があった。しかし読みとれない半のもあり， 各分画例数を示し得なかった。

2. PAS 染色像 (Fig. 2, Table 2)

PAS 染色を行った電気泳動像はFig. 2 に示すよj に, $\gamma$-glob 領域の原点付近ではNos.45, 47, 15のよう に 2 本のバンドがみられるものは54総娭体中 20 検体

(37\%)あり，No.51のようにバンドのないものは33検 体 $(61 \%)$ あった， $\gamma$-glob 領域の陽極側には，多くの 検体でバンドが存在せず (87\%)，1－2 本みられた検 体が少しあった (13\%)， $\alpha$-glob 領域のバンドをみる と主バンドは 54 検体中 52 検体 $(96 \%)$ が，主バンドの 陰極側にある二大バンドの 1 つは 46 検体 (85\%) がそ れぞれ染色された， $\alpha$-glob 領域主バンドの陽極側に は，幅広く染まるバンドが32検体 $(59 \%)$ にみられた。 alb 領域には濃度差があるが, 全例において1本のバ ンドが存在した $(100 \%)$.

Table 1. Numbers and locations of PAG-slab electrophoretical bands of sweat proteins obtained from 52 healthy adult men, CBB staining.

\begin{tabular}{c|cc|c|c|c|c}
\hline \multirow{2}{*}{$\begin{array}{c}\text { Numbers } \\
\text { of bands }\end{array}$} & \multicolumn{2}{|c}{ Sweat bands in regions of electrophoretical mobilities of serum fractions } \\
\cline { 2 - 6 } & $\begin{array}{c}\gamma \text {-glob } \\
\text { original side }\end{array}$ & anodal side & $\beta$-glob & Tf & $\alpha$-glob & alb \\
\hline & Nos. (\%) & Nos. $(\%)$ & Nos. (\%) & Nos. (\%) & $\begin{array}{c}\text { Nos. }(\%) \\
4(8)\end{array}$ & Nos. (\%) \\
5 & & & & & $20(38)$ & \\
3 & & & & & $21(40)$ & \\
2 & $34(65)$ & $3(6)$ & & & $6(12)$ & \\
1 & $7(13)$ & $18(35)$ & $1(2)$ & $9(17)$ & & $52(100)$ \\
0 & $4(8)$ & $31(60)$ & $51(98)$ & $43(83)$ & & \\
unclear & & & & & & \\
\hline
\end{tabular}




\section{（86）生物物理化学}

pre-alb 領域には，移動度の異なる境界の明確でな い3 種のバンドが存在するように観察された。すなわ ち, Fig. 2 の Nos.47，51のよjに速く移動するバンド をもつもの(19\%)，Nos.38，45のように遅く移動する バンドをもつもの (41\%)，No.15のよjに両方のバン ドにかかる広いバンドをもつものがあった $(41 \%)$.

\section{考察}

\section{1. 汗の中の血清成分}

汗に血清成分があるとした報告のうち，albに関し ては, Cier ら ${ }^{9}$ は濾紙電気泳動で alb の移動度に一致 して1本のバンドをみており, Uyttendaele ら ${ }^{13}$ は, 等 速電気泳動で主バンドは alb に相当することを報告し た. Page and Remington ${ }^{10)}$ は二元免疫拡散法で IgG はじめalbを含め 8 種の血清成分が存在することを見 出した。またHerrmann and Habbig ${ }^{17}$ は，汗には血 清蛋白に由来する alb，Tf，IgG があることを報告し た。本研究では，54人の男性の汗の CBB 染色と PAS 染色のいずれにも，対照としたヒト血清の alb と同一 移動度を示すバンドがみられ，ヒト汗には血清 albに 相当する分画があると考之られる結果を得た。 以上， 汗の採取法, 検查法の差などはあるにしても，上卜汗 に血清 albに相当する蛋白が存在すると考えられる。 本研究で, $\gamma$-glob 領域の原点付近にバンドをみる汗 検体が相当あり，これは殿粉ゲル電気泳動でしらべた Cier ら ${ }^{9)}$ の Post $\gamma$, あるいは Page and Remington ${ }^{10)} の$ いう $\gamma$-globの陰極側にある分画に相当すると思われ る. $\gamma$-glob 領域の陽極側にバンドをみたのは $40 \% て ゙$,

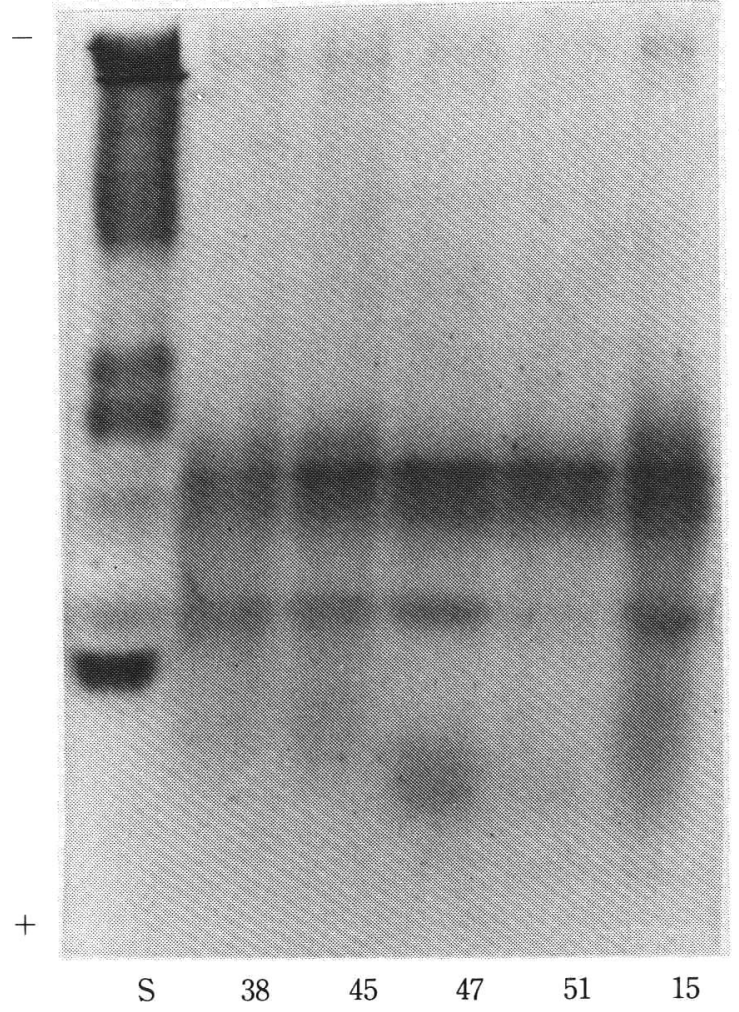

Fig.2. PAG electrophoretic patterns of human sweat and serum, PAS staining.

S : Normal human serum, Nos : Sweat sample numbers.

Table 2. Numbers and locations of PAG-slab electrophoretical bands of sweat proteins obtained from 54 healthy adult men, PAS staining.

\begin{tabular}{|c|c|c|c|c|c|c|}
\hline \multirow{3}{*}{$\begin{array}{l}\text { Numbers } \\
\text { of bands }\end{array}$} & \multicolumn{6}{|c|}{ Sweat bands in regions of electrophoretical mobilities of serum fractions } \\
\hline & \multicolumn{2}{|c|}{$\gamma$-glob } & \multirow{2}{*}{$\alpha$-glob } & \multirow{2}{*}{ alb } & \multirow{2}{*}{\multicolumn{2}{|c|}{ pre-alb }} \\
\hline & original side & anodal side & & & & \\
\hline & Nos. $(\%)$ & Nos. $(\%)$ & Nos. $(\%)$ & Nos. $(\%)$ & Mobility I & Nos. $(\%)$ \\
\hline 4 & & & $5(9)$ & & & \\
\hline 3 & & & $25(46)$ & & fast & $10(19)$ \\
\hline 2 & $20(37)$ & $1(2)$ & $21(39)$ & & fast & $22(41)$ \\
\hline 1 & $1(2)$ & $6(11)$ & $1(2)$ & $54(100)$ & and slow & N \\
\hline 0 & $33(61)$ & $47(87)$ & & & slow & $22(41)$ \\
\hline unclear & & & $2(4)$ & & & \\
\hline
\end{tabular}


バンド数は 1 ～本である。これら $\gamma^{- \text {glob 領域の原 }}$ 点付近および陽極側に出現したバンドが, $\gamma$-globに相 当すると思われるが，その種類は不明であった。

$\beta$-glob 領域に扔ける汗の蛋白バンドの存在は濾紙 電気泳動 ${ }^{917)}$, セルロースアセテート膜電気泳動 ${ }^{10)}$, 免 疫電気泳動の各法で認められてはいるが，一般にバン ドが存在するという報告は少ない。本研究では， $\beta$ glob 領域における汗蛋白のバンドは CBB 染色で僅か 1 検体にみられたのみであり，この領域に泳動される 分画は少ないものとみられる。ヒ卜汗に Tf があると した報告があり ${ }^{10) 13) 17)}$, 本研究でも血清 Tf の付近にバ ンドをみたものが $17 \%$ あった。

\section{2. ヒ上汗の電気泳動像の多様性について}

ヒ卜汗検体の $\mathrm{CBB}$ 染色電気泳動像をみるに，検体 の蛋白量を $0.07 \mathrm{mg}$ と一定にして泳動したにもかかわ らず，Fig. 1，No.36汗検体のように albの濃染するも のと，そうでないものとがあり，染色程度は検体によ ク異なっていた，PAS 染色の電気泳動像でも $\mathrm{CBB}$ 染 色と同様であり，七ト汗の alb 分画には量的に個人差 があると推定される。

$\gamma^{-}, \beta$-各 glob 領域，Tf 領域における各バンドにつ いては前項に述べたが, これら領域におけるヒト汗検 体バンド数, 位置に多様性があり，これは，汗検体の この分画蛋白に濃度差があることを考慮にいれても， なお多様性を否定することはできないと考えられる。

$\alpha$-glob 領域に汗蛋白の分画があることは知られて おり 910101318)，Page and Remington ${ }^{10)}$ は，セルロース アセテート膜電気泳動で, この領域に最も強いバンド がみられたとしている。本研究では, $\mathrm{CBB}$ 染色でも PAS 染色でもこの領域の主バンドはほぼ総ての汗検 体に良く染色されてみられた。 Herrmann and Habbig $^{18}$ は は， $\alpha$-globの移動度をもつ非特異的なカル ボキシルエステラーゼは血清蛋白由来であろうとした が, それは別として, 本研究でみられた $\alpha$-glob 領域主 バンドは，汗の重要な成分の 1 つと考えられる.ただ, その量ないし汗の他のバンドに対する比率は一定では ないと思われる。 $\alpha$-glob 領域主バンドの陰極側にもほ ぼ全検体に出現するバンドがあり，この二大バンドは 汗特有のものと推定される.

一方，この二大バンドを含め， $\alpha$-glob 領域には 2 ～ 5 本のバンドがみられ, 特に Fig. 1 No.22のよう に, 主バンドの $\mathrm{CBB}$ 染色が淡く，その陰極側にあるバ ンドが最も濃く染るという検体もあり， $\alpha$-glob 領域に
も電気泳動像に多様性がみられる.

pre-alb 領域に汗蛋白分画があるとされてお $\eta^{9110)}$, Takizawa ら ${ }^{199}$ は, この領域に泳動される糖蛋 白がヒト汗の特異抗原であるとしている.本研究でも, PAS 染色で移動度の異なる 3 種のバンドを観察して おり,この領域におけるバンドにも多様性がみられる.

以上，ヒ卜汗検体には，各領域においてバンドの多 様性の存在することについて述べたが，汗検体はただ 1 回の採取により得た汗を検査したものであり, 採取 する時期または方法を変えて反復検査し, 同一人が同 一の電気泳動像を示すならば, 上述のバンドの多様性 は個人差によると考えることが出来るであろう．

\section{要旨}

サウナで採取した健康な男性54名の汗について PAG 平板ディスク電気泳動し, CBB 染色と PAS 染 色を行い, 次の結果を得た。 ヒト汗には血清に相当す るバンドが全例において認められ, $\alpha$-glob 領域には汗 の重要な成分と思われる 2 個のバンドがみられた， $\alpha$ ,$- \beta-, \gamma-$ 各 glob 領域で汗バンドの多様性がみられた. pre-alb 領域には移動度の異なる 3 種の糖蛋白と思わ れるものがあった。

\section{文献}

1) 石井康允：長崎医会誌，29：630, 1954.

2) 中嶋八良, 川村一枝：犯罪学誌, $22: 31$, 1956.

3 ）実繁幸男他：科警研報告, $31: 13,1978$.

4) Yada, S. : Japan, J. Med, $16: 290,1962$.

5 ）赤石 英他：日法医誌, 19：181, 1965.

6 ）有馬 孝：科警研報告, $32: 181,1979$.

7 ) 井上晃孝, 岡田吉郎：日法医誌，32：66, 1978.

8 ) Jirka, M. and Kotas, J. : Clin. Chim. Acta, 2 : 292, 1957.

$9)$ Cier, J.F. et al. :C.R.Soc. Biol, $157: 1623$, 1963.

10) Page, C.O. and Remington, J.S. : J. Lab. Clin. Med, 69 : 634, 1967.

11) Jirka, M. and Blanicky, P. : Clin. Chim. Acta, 31:329, 1971.

12) Herrmann, W.P. and Habbig, J. : Arch. Dermatol Res, 255: 63, 1976.

13) Uyttendaele, K. et al. : J. Chromatogr, $132: 261,1977$.

14) Rubin, R.W. and Penneys, N.S. : Anal. Bio- 
（88）生物物理化学

chem, $131: 520,1983$.

15) Jirka, M. and Masopust, J. : Nature, 199 : 283, 1963.

16) Jirka, M. and Masopust, J. : Biochim. Biophys Acta, $71: 217,1963$.

17) Herrmann, W.P. and Habbig, J.: Arch. Dermatol Res, 255 : 123, 1976.

18) Herrmann, W.P. and Habbig, J.: Br. J Dermatol, 95:67, 1976.

19) Takizawa, H. et al.:Proc. Japan Acad, 59 B : 243,1983 .
20) Davis, B.J. : Ann. N. Y. Acad. Sci, 121 : 404, 1964.

21）月刊 Medical Technology 編：電気泳動法の すべて, 1版, 医歯薬出版株式会社, 東京, 1983, p17.

22) Lowry, O.H. et al. : J. Biol. Chem, 193 : $265,1951$.

23）電気泳動学会：電気泳動便覧，1983, p42. 